\title{
FACTORS OF ORGANIZATIONAL CULTURE RELATED TO ORGANIZATIONAL EFFECTIVENESS IN THE SATKES KODIKLATAL
}

\author{
Mega Nurmalasari Wira Putri ${ }^{1}$, Djazuly Chalidyanto². \\ ${ }^{1}$ Departement of Administration and Health Policy, Universitas Airlangga, Surabaya \\ Jalan Dr.Ir.H Soekarno, Mulyorejo, 60115
}

\begin{abstract}
Organizations exist because of human needs through relationships, interactions, communications, socialization to one another to meet common goals. Organizational culture becomes an important part of this influence on organizational effectiveness (a term for the fulfillment of organizational goals). This study aims to determine how the organizational culture conditions of the Kodiklatal Health Unit by using indicators according to the Denison organizational culture model, namely involvement, consistency, adaptability and mission. In addition, a theoretical study on the importance of organizational culture from the background for this research is because the Kodiklatal Satkes is a work unit under the Kodiklatal, which has duties other than carrying out health services for all military and civil servants who serve in Kodiklatal, all students who are carrying out education at Kodiklatal and Family members of military and civil servants Kodiklatal, also carry out health support for every military activity / training carried out by students and members of the Kodiklatal military. The research method is a quantitative method by collecting data using a questionnaire with a sample population of 50 employees of the Kodiklatal Health Unit, processed using descriptive statistics. The results showed that the average overall organizational culture was in the very weak category with the strongest score on the mission sub-variable and the weakest on the involvement sub-variable.
\end{abstract}

Keywords: Culture, Organization, and Denison.

\section{INTRODUCTION}

An organization is a consciously coordinated social entity (entity), with identifiable limitations, which works on a relative continual basis to meet common goals and / or group goals (Robbins \& Matthew, 2009). Organizational effectiveness is a term for the fulfillment of organizational goals (Robbins \& Matthew, 2009). Organizational culture is important because it is related to organizational effectiveness. It is empirically proven that there is a relationship between organizational culture and organizational effectiveness (Alvesson, 2002) and job satisfaction (Maxwell \& Garbarino, 2010). Organizational culture is an important part of organizational resources (Barney, 1986; Javidan, 1998). Organizational culture affects every aspect of the organization (Saffold, 1988). Culture is considered as part of an important element that can help organizations to anticipate and adapt to environmental changes, and maintain performance in order to achieve long-term economic performance success (Kotter \& Heskett, 1992). Culture can be the greatest asset because it allows organizations to achieve strong results and performance or even culture can also be an obstacle to success (Scafone, 2005; Lestari et.al, 2013).

Measuring organizational culture is done by using certain measurement instruments that can only measure groups/ teams with indicators; whether it is included in the very strong, strong, weak and very weak categories of organizational culture tendencies (Veithzal, 2006). This measurement has an impact on knowing the cultural conditions of the Satkes Kodiklatal organization. The absence of empirical research on organizational culture at the Kodiklatal Health Unit also contributes to the background of this research problem. It is hoped that after the measurement of organizational culture at the Kodiklatal Health Unit is known, it will provide correct information about the cultural conditions of the Kodiklatal Health Unit and sufficiently contribute to shaping the culture. The model to be used in this study is the Denison model because it is complete enough to measure the degree of cultural internalization in an organization and this model consists of sub- 
variables which explain that organizational culture has a positive and significant effect on organizational effectiveness (Fey \& Denison, 2003).

\section{RESEARCH METODOLOGY 2.1 Design Research}

From the point of view of the level of explanation, this data collection is classified as descriptive, namely data collection is done to determine the value of the independent variable, either one or more (independent) variables, to describe and explain the existing situation based on facts collected and arranged systematically without making comparisons or linking one variable to another (Sugiono, 2011).

\subsection{Research Procedure}

The method used in data collection using quantitative techniques, namely the data taken is data in the form of numbers or qualitative data which are extrapolated (Sugiono, 2011). The quantitative data collected is primary data, namely data collected for a specific purpose (Sugiono, 2011). The data collection tool is a questionnaire. The questionnaire was arranged based on the variables according to Denison consisting of involvement, consistency, adaptability and mission (Denison \& Mishra, 1995; Kotter \& Heskett, 1992; Alveson, 2002).

\subsection{Data Collection}

The number of questionnaires distributed is 50 questionnaires. Determination of the number of respondents in accordance with the number of questionnaires distributed based on the total sample population. Data analysis was based on descriptive statistical calculations. The use of a measuring scale in the questionnaire is divided into 4 answer choices for each statement item: SS (Strongly agree), S (Agree), TS (Disagree), STS (Strongly Disagree).

Table 1 Operational Variable (Denison Consulting, 2009).

\begin{tabular}{|c|c|l|}
\hline Variable & Sub Variable & \multicolumn{1}{|c|}{ Concept } \\
\hline $\begin{array}{c}\text { Organizational } \\
\text { culture }\end{array}$ & Adaptability & $\begin{array}{l}\text { The level of an } \\
\text { individual's } \\
\text { ability to } \\
\text { translate the } \\
\text { demands of the } \\
\text { external }\end{array}$ \\
\hline
\end{tabular}
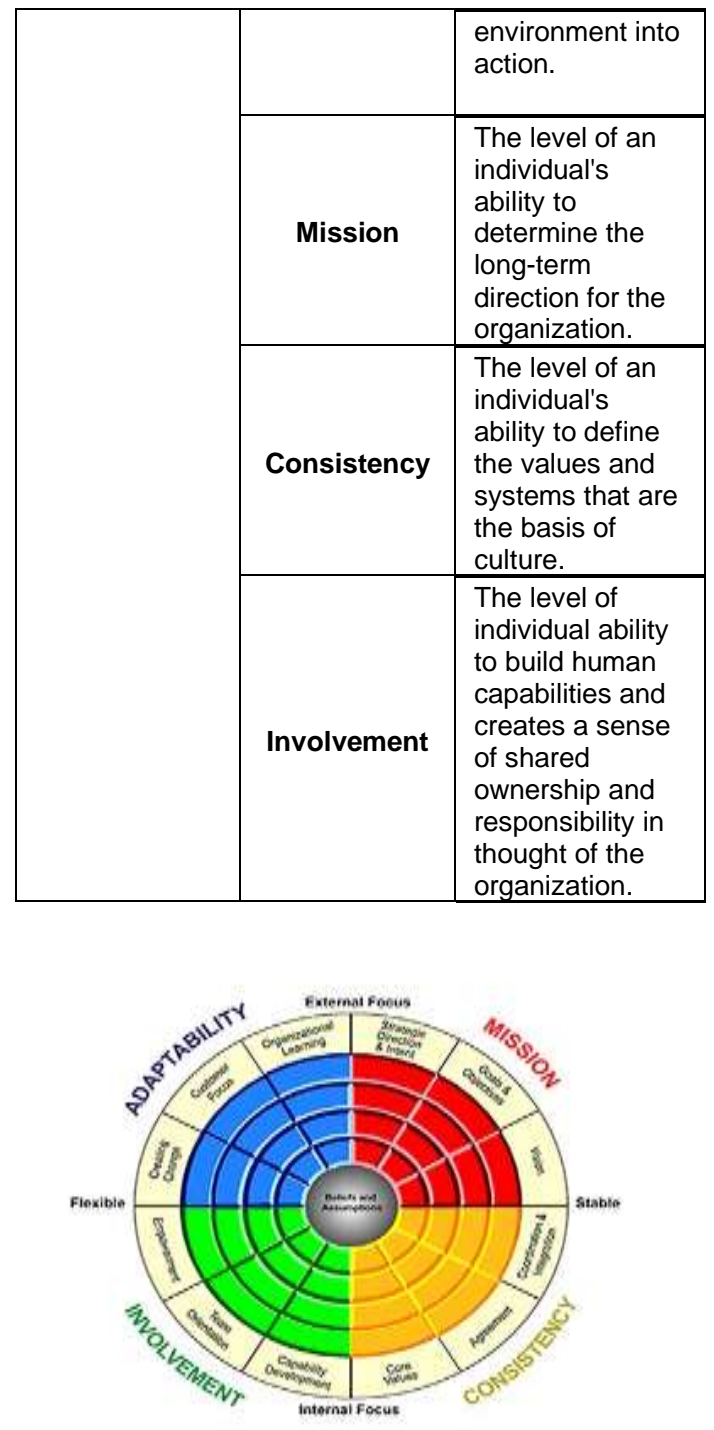

Figure 2.1 Dennison Model

(Source: www.dennisonconsulting.com)

\subsubsection{Descriptive Statistics Calculation}

The number of scores of respondents who answered:

$\begin{array}{ll}\text { SS (Strongly agree) } & \times 4 \\ \text { S (Agree) } & \times 3 \\ \text { TS (Disagree) } & \times 2 \\ \text { STS (Strongly Disagree) } & \times 1\end{array}$

Then the ideal number for all items $=4$ x 50 (number of samples) $=200$ (strongest score: SS). Total weakest score $=1 \times 50=$ 50 (STS). Then the assessment criteria for each statement item are based on the percentage with the following calculations (Arikunto, 2002): The smallest percentage value is $(50 / 200) \times 100 \%=25 \%$. Value range $=100 \%-25 \%=75 \%$, if divided by 4 
measurement scales, the percentage interval value is $18.75 \%$, so the criteria for the value are as follows:

Table 2 Value Interpretation Criteria

\begin{tabular}{|c|c|c|}
\hline No. & Percentage & Category \\
\hline 1 & $25 \%-43.75 \%$ & Very weak \\
\hline 2 & $>43.75 \%-62.5 \%$ & Weak \\
\hline 3 & $>62.5 \%-81.25 \%$ & Strong \\
\hline 4 & $>81.25 \%-100 \%$ & Very strong \\
\hline
\end{tabular}

\subsubsection{Descriptive Statistical Analysis Regarding Organizational Culture Variables}

\subsubsection{Adaptability Sub Variable}

Table 3 Results of Calculation of Descriptive Statistics for Sub Adaptability Variables

\begin{tabular}{|c|c|c|}
\hline No & Statement Items & $\begin{array}{l}\text { Score } \\
\text { Total (\%) }\end{array}$ \\
\hline 1. & $\begin{array}{l}\text { I am used to developing } \\
\text { new breakthroughs to } \\
\text { produce better } \\
\text { performance. }\end{array}$ & $37 \%$ \\
\hline 2. & $\begin{array}{l}\text { I am open to new } \\
\text { information or } \\
\text { knowledge. }\end{array}$ & $53 \%$ \\
\hline 3. & $\begin{array}{l}\text { I show initiatives to } \\
\text { identify opportunities for } \\
\text { improvement that can } \\
\text { add value to the } \\
\text { organization. }\end{array}$ & $50 \%$ \\
\hline 4 & $\begin{array}{l}\text { I am proactive in } \\
\text { improving service quality }\end{array}$ & $31 \%$ \\
\hline 5 & $\begin{array}{l}\text { I act fairly in providing } \\
\text { services }\end{array}$ & $27 \%$ \\
\hline
\end{tabular}

\begin{tabular}{|l|l|l|}
\hline 6 & $\begin{array}{l}\text { I show caring, friendly } \\
\text { and polite in providing } \\
\text { services. }\end{array}$ & $38 \%$ \\
\hline 7 & $\begin{array}{l}\text { I always provide } \\
\text { services that are timely, } \\
\text { fast and transparent. }\end{array}$ & $50 \%$ \\
\hline 8 & $\begin{array}{l}\text { I get directions to be } \\
\text { able to evaluate work / } \\
\text { ministry. }\end{array}$ & \begin{tabular}{l}
$16 \%$ \\
\hline 9
\end{tabular} \\
$\begin{array}{l}\text { I dare to put forward } \\
\text { positive ideas / } \\
\text { opinions that add } \\
\text { value to the progress } \\
\text { of the organization. }\end{array}$ & $\mathbf{1 5 \%}$ \\
\hline Average & $38 \%$ \\
\hline
\end{tabular}

From the table above, overall, the subadaptability variable is categorized as very weak (38\%).

\subsubsection{Mission Sub Variable}

Table 4 Descriptive Statistics Calculation Results of Mission Sub Variables

\begin{tabular}{|c|c|c|}
\hline No & Statement Items & $\begin{array}{c}\text { Score } \\
\text { Total (\%) }\end{array}$ \\
\hline 10 & $\begin{array}{l}\text { I know the vision of the } \\
\text { organization, and feel that it } \\
\text { can create passion and } \\
\text { motivation for employees. }\end{array}$ & $68 \%$ \\
\hline 11 & $\begin{array}{l}\text { I am able to meet short-term } \\
\text { demands without compromising } \\
\text { the long-term vision of the } \\
\text { organization. }\end{array}$ & $48 \%$ \\
\hline 12 & $\begin{array}{l}\text { Every leader has a long-term } \\
\text { thinking point of view. }\end{array}$ & $26 \%$ \\
\hline 13 & $\begin{array}{l}\text { I know the mission of the } \\
\text { organization and understand its } \\
\text { meaning and alignment with } \\
\text { task completion. }\end{array}$ & $30 \%$ \\
\hline 14 & $\begin{array}{l}\text { I know the organizational } \\
\text { strategy and feel the strategy } \\
\text { implemented will work. }\end{array}$ & $54 \%$ \\
\hline 15 & $\begin{array}{l}\text { I monitor the realization of the } \\
\text { achievement against the targets } \\
\text { set. }\end{array}$ & $51 \%$ \\
\hline 16 & $\begin{array}{l}\text { Each leader sets ambitious but } \\
\text { realistic organizational goals. }\end{array}$ & $24 \%$ \\
\hline 17 & $\begin{array}{l}\text { The organizational strategy } \\
\text { directions / directions are clear. }\end{array}$ & $33 \%$ \\
\hline \multicolumn{2}{|c|}{ Average } & $42 \%$ \\
\hline
\end{tabular}


Overall, the mission sub-variable was in the very weak category with the percentage $42 \%$.

\subsubsection{Consistency Sub Variable}

Table 5 The Result of Calculation of Descriptive Statistics of Consistency Sub Variable.

\begin{tabular}{|c|c|c|}
\hline No & Statement Items & $\begin{array}{c}\text { Score } \\
\text { Total (\%) }\end{array}$ \\
\hline 18 & $\begin{array}{l}\text { I know the core values of the } \\
\text { organization, which control the } \\
\text { way employees carry out } \\
\text { organizational activities. }\end{array}$ & $18 \%$ \\
\hline 19 & $\begin{array}{l}\text { I understand that ignoring the } \\
\text { core values of the } \\
\text { organization will get me into } \\
\text { trouble. }\end{array}$ & $54 \%$ \\
\hline 20 & $\begin{array}{l}\text { I know the organization's code } \\
\text { of conduct, which guides } \\
\text { employee behavior in } \\
\text { determining what is right or } \\
\text { wrong. }\end{array}$ & $54 \%$ \\
\hline 21 & $\begin{array}{l}\text { I am able to demonstrate a } \\
\text { commitment to joint decisions } \\
\text { and their implementation. }\end{array}$ & $29 \%$ \\
\hline 22 & $\begin{array}{l}\text { The employees here have the } \\
\text { same feeling that the Satkes } \\
\text { Kodiklatal has a strong } \\
\text { organizational culture. }\end{array}$ & $22 \%$ \\
\hline 23 & $\begin{array}{l}\text { Employees here have a clear } \\
\text { agreement on the right and } \\
\text { wrong in carrying out their duties } \\
\text { and responsibilities. }\end{array}$ & $20 \%$ \\
\hline 24 & $\begin{array}{l}\text { I prioritize coordination and } \\
\text { establish and maintain } \\
\text { cooperation. }\end{array}$ & $32 \%$ \\
\hline 25 & $\begin{array}{l}\text { I share information and data with } \\
\text { other employees, according to } \\
\text { my authority. }\end{array}$ & $49 \%$ \\
\hline 26 & $\begin{array}{l}\text { In carrying out my duties and } \\
\text { responsibilities, I am always } \\
\text { oriented towards the interests } \\
\text { of the organization (not } \\
\text { individually / in groups). }\end{array}$ & $17 \%$ \\
\hline & Average & $33 \%$ \\
\hline
\end{tabular}

From the results of the descriptive statistical calculations above, it can be seen that the consistency of the sub-variable conditions of the Kodiklatal Health Unit consistency is in the very weak category, namely $33 \%$.

\subsubsection{Involvement Sub Variable}

Table 6 Results of Sub-Variable Engagement Statistics Calculation

\begin{tabular}{|c|c|c|}
\hline No & Statement Items & $\begin{array}{c}\text { Score } \\
\text { Total (\%) }\end{array}$ \\
\hline 27 & $\begin{array}{l}\text { I can access and get the } \\
\text { information needed. }\end{array}$ & $17 \%$ \\
\hline
\end{tabular}

\begin{tabular}{|c|l|c|}
\hline 28 & $\begin{array}{l}\text { I acted according to the } \\
\text { rules even though I wasn't } \\
\text { being watched. }\end{array}$ & $50 \%$ \\
\hline 29 & $\begin{array}{l}\text { I always improve my } \\
\text { competence. }\end{array}$ & $34 \%$ \\
\hline 30 & $\begin{array}{l}\text { I am able to work in a team } \\
\text { and always make the best } \\
\text { contribution. }\end{array}$ & $26 \%$ \\
\hline 31 & $\begin{array}{l}\text { I always maintain } \\
\text { togetherness and equality } \\
\text { among others. }\end{array}$ & $35 \%$ \\
\hline 32 & $\begin{array}{l}\text { The work here is well } \\
\text { organized so that every } \\
\text { employee is able to see the } \\
\text { relationship between his job } \\
\text { and organizational goals. }\end{array}$ & $42 \%$ \\
\hline 33 & $\begin{array}{l}\text { I feel involved in identifying } \\
\text { possible risks and taking } \\
\text { preventive measures. }\end{array}$ & $26 \%$ \\
\hline 34 & $\begin{array}{l}\text { I was given the authority to } \\
\text { act according to the level of } \\
\text { authority. }\end{array}$ & $\begin{array}{l}\text { I have the same opportunity } \\
\text { to get training to improve } \\
\text { skills. }\end{array}$ \\
\hline & $32 \%$ \\
\hline 35 & $26 \%$ \\
\hline
\end{tabular}

From the results of the descriptive statistical calculations above, it can be seen that the consistency of the sub-variable condition of the Kodiklatal Health Unit is in the very weak category, namely $33 \%$.

Thus, it can be concluded that the results of the interpretation are in the following table:

Table 7. Interpretation Criteria for Organizational Culture Variables in the Health Unit Kodiklatal.

\begin{tabular}{|c|l|c|c|c|c|c|}
\hline \multirow{2}{*}{ No } & \multirow{2}{*}{ Sub Variable } & $\begin{array}{c}\text { Very } \\
\text { Weak }\end{array}$ & Weak & Strong & $\begin{array}{c}\text { Very } \\
\text { Strong }\end{array}$ & $\begin{array}{c}\text { Infor } \\
\text { matio } \\
\mathrm{n}\end{array}$ \\
\cline { 3 - 6 } & & $\begin{array}{c}25 \%- \\
4,75 \%\end{array}$ & $\begin{array}{c}43,75 \% \\
-\end{array}$ & $\begin{array}{c}62,5 \%- \\
81,25 \%\end{array}$ & $\begin{array}{c}81,25 \%- \\
100 \%\end{array}$ & \\
\hline 1 & Adaptability & & - & - & - & $38 \%$ \\
\hline 2 & Mission & & - & - & - & $42 \%$ \\
\hline 3 & Consistency & & - & - & - & $33 \%$ \\
\hline 4 & Involvement & & - & - & - & $32 \%$ \\
\hline
\end{tabular}

From the results of data processing using descriptive statistics, it shows that the overall organizational culture of the Kodiklatal Health Unit is still in the very weak category, namely $32 \%$. The mission sub-variable was the sub-variable with the strongest percentage $(42 \%)$ and the involvement subvariable was the sub-variable with the weakest percentage (32\%). 


\section{RESULT AND DISCUSSION}

\subsection{Discussion}

The explanation of the results of descriptive statistical calculations will answer the formulation of the problem based on the background of the problem, namely the empirical condition of the organizational culture of the Kodiklatal Health Unit is not known. This indicates that the organizational culture in general shows that it does not support the fulfillment of its organizational effectiveness (organizational goals, vision and mission).

\subsubsection{Adaptability sub variable}

From the nine statements, the adaptability sub-variable briefly describes how the habit patterns of a worker who contribute actively, proactively, have the initiative to want to learn related to work and the progress of their organization. From the table and continuum line drawing above, the overall adaptability sub-variable is categorized as very weak (32\%). The adaptability sub-variable can be seen from 2 things, namely the perspective of the organization's external environment and flexibility. Meanwhile, it can be interpreted that according to the members, the Kodiklatal Health Unit is less flexible to follow developments in the external organizational environment.

The external environment of the Kodiklatal Satkes requires a fairly strong level of service, considering that the Kodiklatal Satkes has a duty in addition to carrying out health services as well as carrying out health support in addition to other tasks. The importance of adaptibility to the external environment (influence of the external environment) because it determines the point of dependency of the organization (Thompson, 1967). Another thing has also been explained that the external environment of the organization is an environment whose changes are quite fast (tends to be dynamic) and is less predictable, therefore the organization will take anticipatory actions to increase the likelihood of meeting the organizational goals.

Adaptability is how organizational members adapt to the regulations and changes in the organization's external environment. The openness of the members of the Satkes Kodiklatal organization to new things shows that they are still in the weak category, $53 \%$. This statement item is the item with the largest percentage. Meanwhile, the very weak category was shown by the courage of the members of the organization to put forward positive ideas / opinions which provided added value for the progress of the organization, namely $15 \%$. Especially for the item of the statement of courage to express positive ideas / opinions that provide added value for the progress of the organization, it is recommended to get the top priority for immediate change. This means the members of the Satkes.

Kodiklatal is suggested to be brave in expressing positive ideas / opinions that add value to the progress of the organization. In the future, it can be possible to empirical research on what important matters have the effect of causing someone to dare to express opinions related to positive ideas / opinions that provide added value for organizational progress; literature review on how to increase the courage of a person to express opinions related to positive ideas / opinions that add value to organizational progress and experimental efforts to carry out the two previous studies.

Some of the possibilities that have led to the lack of courage of the members of the organization to express their opinions, among others, the formation of an eastern culture to maintain politeness in expressing opinions. In contrast to western culture which is more open to expressing opinions. Indonesian culture, especially military culture, tends to be centralized (strong formality). The military will tend to form a bureaucratic culture, in the form of a bureaucratic organization it will shape the tendency of members of the organization to be less courageous in expressing their opinions. This condition is not suitable for the digital era. Where this digital era requires an organizational design with distributed information dissemination. The need for changes to start expressing opinions on ideas for the advancement of organizations that adapt to the digital era in the corridor of Indonesian culture that is rooted in the values of Pancasila.

\subsubsection{Mission Sub Variable}

The point of view of the mission subvariable can be seen from the organization's external environment and stability (matters concerning formalization, written rules, routines, routines). How everyone in the organization knows, understands, is involved in jointly carrying out 
the mission that has been mutually agreed upon to meet organizational goals, especially those relating to the external organizational environment. In the sub mission variable, there are 2 extreme points, namely the weakest and strongest points.

For the strongest point, $68 \%$ of the statement items know the organization's vision, and feel that this vision can create passion and motivation for employees. This may imply that according to respondents' perceptions, they expressed their opinion that most respondents knew the vision of the organization and felt that this vision was able to create their passion and motivation. The weakest point stated by the leadership statement item sets an ambitious but realistic organizational target with $16 \%$. This means that the respondents perceive leadership as not setting ambitious and realistic targets when viewed in the context of the digital era. The theoretical target setting uses the SMART principle (Drucker, 1954), namely specific (Specific), measurable (Measurable), attainable (Attainable), realistic (Realistic) and there is a measure of time (Time).

A leadership statement item can set ambitious but realistic organizational targets. of the mission sub-variables get the first priority to suggest improvement efforts. This concerns how leaders set challenging and realistic targets. Does the leader know the SMART concept? Can the leadership understand and set targets using the SMART concept correctly? It is recommended that the organization's goals be adjusted to the current and future digital era and globalization. Realistically looking at the current organizational conditions compared to the goals so that gaps can be identified so that further steps are drawn up gradually and quickly to be able to meet them. This of course requires collaboration of all members of the organization. For this reason, the challenge for leaders is to collaborate with all members of the organization so that they can jointly fill the gap. Organizational mapping can be done based on the character background and competence of each person in order to fulfill the goal of the right man on the right place.

\subsubsection{Consistency Sub Variable}

The point of view of the consistency sub variable is seen from the organization's internal environment and stability. The internal conditions of the organization relate to stable conditions (presence of regulations, standards, routine activities, formalities). Internally it can be interpreted that the condition of the leadership and staff in carrying out all daily activities based on values, code of ethics, togetherness, agreement in order to meet organizational goals still needs to be improved. Consistency is how the members of the organization are a continuous unit together proportionally to meet organizational goals.

From the consistency sub variable, the strongest statement item achieved by the employee statement item understands that ignoring the organization's core values will lead to personal difficulties and the employee's statement of understanding the organizational code of ethics, which guides employee behavior in determining what is right or wrong with $54 \%$ namely knowledge, understanding the importance of values and code of ethics. This means that members of the organization know enough about the importance of values and code of ethics in the organization, just because they are still in the weak category, this should still need to be improved. To know and understand the values and code of ethics in the organization, it is necessary to do socialization, feedback and role models.

For the weakest statement items, namely the implementation of tasks that are carried out oriented towards the interests of the organization with a value of $17 \%$. This means that the work orientation of organizational members is still not in the interests of the organization. Items with the weak percentage in the consistency sub variable will get priority for suggestions for improvement. It is suggested that there should be notification of the importance of orientation to the organization for the interests of the internal environment of the Kodiklatal Health Unit which is obtained from a literature study, the preparation of a work system designed so that each member of the organization works for the benefit of the organization. After that it is also necessary to hold periodic evaluations to ensure any changes related to the system design that have been compiled and implemented.

Matters related to the orientation of organizational interests related to organizational commitment. It is necessary to form patterned behavioral habits that are carried out by most members of the organization starting from the leaders (because they are done continuously) to 
realize the actions of the members of the organization whose orientation is for the good of the organization. To make this happen, it is also necessary to have a common perspective on the important values of the organization and how to implement them in daily activities. Other things also need to be known and experienced directly regarding the positive effects of the implementation of organizational values that are carried out in daily activities. By being known, understood and experienced directly, it is hoped that commitment will arise within each member of the organization.

\subsubsection{Involvement Sub Variable}

The perspective of the sub-variable involvement can be seen from the flexibility of the organization's internal environment. Flexibility in the internal environment of the organization is the freedom for organizational members to have authority in terms of developing, completing work with teamwork, sharing knowledge, opportunities for selfdevelopment. This may imply that the condition of togetherness in carrying out the daily work of organizational members, training to improve skills, authority to act according to authority, risk identification still needs to be improved.

Involvement is a trait that displays the strength of development within the organization as indicated by the attitude of staff who are willing to voluntarily work and follow the rules in the organization, because with the involvement of staff they feel that they are part of the organization, have autonomy and trust to take action or take action. decisions in organizations (Casida, 2007). Involvement here involves individual initiative which is a right as well as an obligation, freedom or independence that each member of the organization has in expressing opinions that support positively the fulfillment of organizational goals. The presence of involvement can indicate that it is possible that members of the organization feel comfortable, and attached.

The specific thing that was observed was the weakest and strongest statement items the percentage of the involvement subvariables. The strongest item is in the statement item that members of the organization act according to the rules even though they are not supervised, which is still in the weak category (50\%). This shows that members of the organization generally still need commitment from each member of the organization. With organizational commitment, there will likely be reduced supervision due to culture, habit patterns to work according to organizational values can run automatically (autopilot).

There is a literary link between engagement and organizational commitment, among others, stated by Shaw, Delery \& Abdulla (2003). According to Meyer and Allan (1995) in Mahampang and Mapuahsari, organizational commitment is composed of: (1) the affective component, namely emotional attachment to the organization where employees identify with the organization and enjoy membership in the organization; (2) Continuance commitment is the tendency to keep working in the organization because the cost of resignation is considered too large. These costs can be in the form of direct costs, indirect costs, as well as costs for the opportunity cost; (3) Normative commitment is a responsibility to stay in the organization. This responsibility can be in the form of a moral burden that causes workers to feel they must belong to the organization. Meanwhile, according to Scott \& Burroughs (1992) organizational commitment is the relative strength of collective individual identification and involvement with the organization.

The weakest item in the item statement is the ease of accessing and obtaining the information needed by $17 \%$, this means that the access and information needed by members of the organization in completing their work still needs to be improved. It is suggested that access to information can be facilitated in order to support members of the organization to fulfill their jobs. As discussed in the previous sub-adaptability variable, access to this information is possible due to the influence of militaristic culture, centralization with strong formalization. There is a need for a change in mindset to adapt to the digital era, where in the digital era, the presence of ICT will facilitate access to information for organizational members in order to provide comfort to work.

Gibson et al. (1997) \& (Pane, 2009) revealed that organizational culture needs to be differentiated into strong and weak cultures. The strength and weakness of organizational culture depends on variables such as cohesiveness, unity, value agreement and individual commitment to 
common goals (Krietner \& Kinicki, 1995; Pane, 2009).

An organization whose culture falls into the strong category can be characterized by the core values of the organization which are carried out routinely with happiness, are well managed and shared. The indication is if more and more members of the organization accept, happily implement the core values of the organization and have a feeling of being very attached to the organization. A strong culture will increase behavior that tends to be stable, consistent (Weick, 1987). Kottler \& Heskett (2006) \& (Pane, 2009) reveal that a strong organizational culture will trigger employees to think, behave and behave in accordance with organizational values. Organizations do not adopt culture in one day and in fact learn from past experiences and start practicing it every day thus shaping the workplace culture. (Schein, 1984). The Satkes Kodiklatal is an organization that can be categorized as young, so it is natural that the results of the measurement of the organizational culture internalization are still very weak and still need improvement.

\section{CONCLUSION}

It can be concluded that the overall organizational culture of the Kodiklatal Health Unit is in the very weak category. From all of the 5 organizational culture variables, the strongest value was obtained from the mission sub-variable and the weakest value by the involvement subvariable.

\section{ACKNOWLEDGEMENT}

The authors greatly acknowledge the support from Airlangga University Surabaya, Indonesia for providing the necessary resources to carry out this research work. The authors are also grateful to Satkes Kodiklatal Naval Technology College, STTAL Surabaya, and the anonymous reviewers and journal editorial board for their many insightful comments, which have significantly improved this article

\section{REFERENCES}

Afiah, Riany Noor. (2013). Budaya Dan Efektifitas Organisasi Rumah Sakit (Di RSUD Haji Makassar Dan Rsu Labuang Baji Makassar. e-journal Program Pascasarjana Universitas Hasanuddin.
Alvesson, Mats. (2002). Understanding Organizational Culture, SAGE Publication, Cambridge University Press.

Barney, J.B. (1986). Types of Competition and the Theory of Strategy: Toward an Integrative Framework. Academy of Management Review, 11, 791-800.

Becker, G. (1964), Human Capital: A Theoretical and Empirical Analysis with Special Reference to Education, New York: Columbia University Press.

Denison, D. R. Mishra, A. K. (1995), "Toward a Theory of Organizational Culture and Effectiveness," Organization Science, 6, 2, 204-223.

Denison, D. R. Neale, W. (1996). Denison Organization Culture Survey. Ann Arbor, MI: http://www.denisonconsulting.com/ad vantage/research Model/model.aspx.

Drucker, Peter. F, (1954). The Practice of Management.

Fey, C.F. Denison, D.R. (2003). Organizational Culture and Effectiveness: Can American theory been applied in Russia, Organization science.

Gibson, James I. Ivancevich, John M. Donnely Jr., James H. (1997). Organisasi dan Manajemen: Perilaku, Struktur, Proses. Edisi 4, terjemahan, Penerbit Erlangga, Jakarta.

Kreitner, Robert. Kinichi, Angelo. (2000). Organizational Behavior, Edisi ketiga USA D Irwin Inc.

Kotter, J.P. Heskett, J.L. (1992), Corporate Culture and Performance, The Free Press, NY.

Pane, J., \& Astuti, S. D. (2009). Pengaruh Budaya Organisasi, Kepemimpinan Transformasional dan Kompensasi terhadap Kinerja Karyawan (Studi pada Kantor Telkom Divre IV di Semarang). TEMA Vol 6 Edisi 1, 6789.

Maxwell, S. Garbarino, E. (2010). The identification of social norms of discrimination on the internet. Journal 
of Management Development. Emerald Group Publishing Ltd.

Mahmudah, H., \& Mapuasari, S. (2015). Komitmen Organisasi, Akuntabilitas Dan Organization Citizenship Behavior Institusi Militer, (Studi Empiris Di Angkatan Udara Republik Indonesia). Research Gate.

Robbins S.P. Matthew M. (2009). Organization Theory: Structure, Design, and Applications. $3^{\text {rd }}$ edition, Pearson Education.

Schein, Edgar H. (1985). Organizational Culture and Leadership. San Fransisco: Jossey Bass.

Shaw, Delery \& Abdulla (2003) Organizational Commitment and Performance Among Guest Workers and Citizens of An Arab Country, Journal of Business Research, 56.

Sun, Shili (2008). Organizational Culture and Its Themes. International Journal of Business aand Management, 3(12), 137-141.

Steers, Richard M. (1985). Efektivitas Organizational Behavior. Magdalena Jamin, Jakarta: LPPM \& Erlangga.

Stoner, James. A.F., Freeman. R. Edward, Gilbert, Daniel R. (1996). Manajemen.PT Prenhallindo. Jakarta.

Sugiyono. (2011). Metode Penelitian Kuantitatif, Kualitatif, dan $R \& D$. Bandung: Alfabeta.

Thompson, James D. (2003) [1967]. Organizations in Action: Social Science Bases of Administrative Theory (With a new preface by Mayer $\mathrm{N}$. Zald and a new introduction by W. Richard Scott ed.). New Brunswick, New Jersey: Transaction Publishers.

Veithzal, Rivai. (2006). MSDM untuk perusahaan dari teori ke praktek. Jakarta; PT. Raja Grafindo Persada.

Weick, Karl. E. (1987). Organizational Culture as a Source of High Reliability. California Management Review. 